\title{
What About Private Kindergarten Teachers' Authentic Leadership? The Role of Personality Traits
}

\author{
Xiaoyao Yue ${ }^{1}$, Yan $\mathrm{Ye}^{1}$, Xu Zheng ${ }^{2}$, Yongjun Feng ${ }^{3}$, Yanan Yang ${ }^{4} \&$ Yuanfan Yang \\ ${ }^{1}$ Graduate school of education, Stamford International University, Bangkok, Thailand \\ ${ }^{2}$ School of Foreign study, Shaoguan University, Shaoguan, Guangdong, China \\ ${ }^{3}$ School of Education, Shaanxi Normal University, Xi'an, Shaanxi, China \\ ${ }^{4}$ Reallearning Institution, Bangkok, Thailand \\ ${ }^{5}$ Peiqi Inclusive Kindergarten, Kunming, Yunnan, China \\ Correspondence: Xiaoyao Yue, Graduate school of education, Stamford International University, Bangkok, \\ Thailand. E-mail: xiaoyao.yue@stamford.edu
}

Received: July 18, 2021

Accepted: August 22, $2021 \quad$ Online Published: August 30, 2021

doi:10.5539/jel.v10n5p187

URL: https://doi.org/10.5539/jel.v10n5p187

\begin{abstract}
The improvement of teacher leadership is the key to promote the quality of kindergarten education. As a kind of teacher leadership, authentic leadership is related to the teacher's personality traits. This paper collects data on the authentic leadership and personality of 157 teachers in three private kindergartens in Kunming, Yunnan Province of China, and validates the research hypothesis that teacher personality can affect teachers' authentic leadership through SPSS analysis. Based on the descriptive analysis and linear regression analysis, it can be seen that the authentic leadership of private kindergarten teachers in Yunnan Province needs to be further improved, and personality as an inseparable part of predicting leadership needs to be re-emphasized. Results also indicate that when testing personality traits, future researchers must use complete questionnaires instead of short questionnaires.
\end{abstract}

Keywords: kindergarten teachers, teacher leadership, authentic leadership, private kindergarten

\section{Introduction}

Research on the quality of early childhood education (ECE) shows that ensuring high-quality education can lead to better child outcomes. This includes acquiring pre-literacy skills and improving social emotions, academic performance, language skills, and classroom behavior. Leadership is a key factor affecting ECE's quality improvement. Teacher leadership is considered to play an important role in the transformation of teaching and learning. It can also be used as a tool to connect key stakeholders and work together to develop a learning community. It provides the means for open communication, trust, harmony, continuous exploration, and improvement (Wang, 2018).

On a global scale, today teachers must take on more leadership roles and carry out their work more broadly. Teaching leadership has more work than ever before (Harris, 2003). In recent years, Western literature has actively discussed the link between leadership and high-quality early childhood education (ECE), because leadership is considered a key element of high-quality ECE (Heikka et al., 2019). Heikka et al. (2018) recommended that teacher leadership is involved in the responsibility of early childhood education pedagogy. The teaching and leadership practices of kindergarten teachers are together because they have multiple responsibilities, that is, they are both teachers and leaders (Heikka et al., 2013). Harris (2003) believes that the top-down management structure is the main obstacle to teacher leadership development because it reduces the autonomy of teachers and limits the leadership role of teachers in schools. Teacher leadership has played a key role in improving the quality of kindergartens. There are only a handful of local studies in China. This research will supplement the literature on the leadership of private kindergarten teachers in the Chinese context and further explore the relationship between personality and teacher leadership. 


\section{Literature Review}

\subsection{Teacher Leadership in ECE}

Leadership has different definitions in the early research period. For example, York-Barr and Duke (2004) proposed seven dimensions of teacher leadership: (a) coordination and management; (b) school or regional curriculum work; (c) professional colleagues' development; (d) participating schools change or improvement; (e) Parent and community involvement; (f) Contribute to the teaching profession; (g) Pre-service teacher education. Harris (2005) emphasized the definition of teacher leadership in four aspects: (a) Develop collegial standards; (b) leadership opportunities; (c) Serving as a teaching leader; (d) Retraining the school. Katzenmeyer and Moller (2009) measure teachers' perceptions of the presence of seven aspects of teacher leadership within their schools, which including (1) developmental focus, (2) recognition, (3) autonomy, (4) collegiality, (5) participation, (6) open communication and (7) positive environment. Lambert (2003) describes leadership as learning together to achieve a common vision, truly combining learning and leadership. She takes advantage of the teacher's leadership abilities, which include a strong focus on ideas, reflection and innovation, co-governance, supervision, and responses to student performance.

In the field of early childhood education, teacher leadership is still a new research topic, and scholars have put forward their theories and concepts. For example, Halttunen, Waniganayake, and Heikka (2019) investigated teacher leadership in the Finland Early Childhood Education (ECE) environment. During weekly team meetings organized by employee teams, researchers used discourse analysis to investigate teacher leadership. In Finland, the staff team usually consists of an early childhood education teacher (i.e., team leader) and two childcare nurses. In this study, early childhood education teachers are understood as teacher leaders. The study identified four aspects of teacher leadership: 1) Collaborative teacher leadership; 2) Supporting teacher leadership; 3) Professional expertise; 4) Legitimacy. Understanding teacher leadership is essential for implementing teaching leadership in the faculty and staff team of the ECE Center. Wang and Xia (2020) established a four-factor model of the leadership of kindergarten teachers. The four factors are as follows: (a) Leading teaching and professional development; (b) Characteristics of teacher leadership; (c) Participation of the whole school in decision-making; (d) Diversity and continuous improvement.

Heikka (2014) has identified five dimensions of distributed instructional leadership in ECE organizations. These dimensions create an interdependent area. The five dimensions include: enhancing the awareness of sharing between stakeholders' visions and strategies, assigning responsibility for teaching leadership, assigning and clarifying the power relationship between stakeholders, assigning the development of teaching improvements in the center, and formulating distributed teaching leadership strategy. Heikka and her colleagues (2021) thought the topic of distributed instructional leadership has aroused the interest of researchers in early childhood education leadership. More and more researches focus on investigating the leadership developed between leaders and teachers in the early childhood education environment. They focus on the implementation of distributed teaching leadership in the Finnish ECE environment and its relationship with teachers' commitment to teaching leadership for faculty and staff teams. The study was designed with an explanatory sequential hybrid method. A survey collected data on the views of 130 ECE professionals, ECE center directors, ECE teachers, and childcare nurses on distributed instructional leadership and teacher commitment. The qualitative survey included six ECE professional interviews. The results show that the studied ECE center adopts a leadership method consistent with distributed teaching leadership, and the implementation of distributed leadership forms is positively related to the ability of ECE teachers to lead reflection and learning in their teams.

\subsection{Teacher Leadership in ECE of China}

Ho, Wang, and He (2019) conducted a theoretical discussion on teacher leadership in the context of changing leadership patterns and explored emerging practices of teacher leadership in China's early childhood education. In 2010, the Chinese central government issued several waves of policies related to teacher professional development to improve and promote the quality of early childhood education. The global discourse developed mainly in the West shows that school leaders play an important role in promoting teacher professional development and education quality. These discourses have influenced China's educational reform agenda, which is reflected in the recently formulated ECE School Leadership Development Strategy. Historically, ECE teachers were regarded as nannies rather than educators, and preschool principals were regarded as policy implementers and school administrators, rather than leaders of school innovation and change. Their research discusses the changing pattern of school leadership in China's ECE and how it is affected by hierarchical culture. Some people believe that the practice of school leadership is largely concentrated in the hands of preschool principals. At the same time, there have been teacher leadership exercised by principals in home-school networks and teaching 
research groups.

Wang and Ho (2019) integrated research on teacher leadership published in English journals from 2000 to 2018. In this study, a systematic evaluation of the methods was used. New perspectives on teacher leadership through theoretical discussions were developed and emerging topics for future research were identified in their investigations. The research first identified relevant literature and research on teacher leadership from English journals from 2000 to 2018. Information about the nature of the research and the researchers discovered was extracted from each article. The synthesis of the results is done by identifying key themes in the literature. Four themes were synthesized: "The concept of teacher leadership", "Theoretical perspective is used to understand teacher leadership", "Factors affecting the development of teacher leadership" and "Methods to establish and develop leadership".

Wang and Xia (2020) used a mixed research method to design a Teacher Leadership Scale (TLS) that can be used in early childhood education in China. This research includes qualitative and quantitative data on middle-level leaders (i.e., vice-principals, key stage coordinators, subject leaders) and class teachers on their perceptions of teacher leadership. In the qualitative research, the leader guided seven classroom teachers and conducted seven semi-structured interviews. The results of the qualitative research were used to make a questionnaire for the quantitative research, and TLS was created in four development stages. The TLS questionnaire was distributed to 175 respondents and then distributed to 419 respondents for exploratory factor analysis. The scale also used an additional 597 interviewees for further confirmatory factor analysis. Also checked its simultaneous effectiveness, teacher leadership is positively correlated with job satisfaction and the principal's openness to authority. The four-factor model of teacher leadership obtained from the research includes: (a) leading teaching and professional development; (b) characteristics of teacher leadership; (c) participation in school-wide decision-making; (d) diversity and continuous improvement.

\subsection{Authentic Leadership of Teacher}

The authentic leadership theories appeared in the year 2000 and are often cited in the early literature because they are forming a fascinating personality, and active and true leadership forms are playing a role (Luss \& Avolio, 2003). The concept of force has been studied for nearly a decade, but a common definition was established by Avolio et al. (2004). They define authentic leaders as "those who have achieved a high degree of authenticity, they know who they are and what they believe". They adopt active organization, belief, hope, simultaneous behavior, and identity to describe the processes of influence between authentic leaders and followers. According to this conceptualization, leaders need to cultivate these qualities to be truly authentic leaders (Avolio \& Gardner, 2005). Antithetic people bear the responsibility to live in a way that fits their truth and core (Wiewiora \& Kowalkiewicz, 2018).

The authentic leadership theory is still in a mature process, so the definition is not clear, and there are many different but interrelated explanations (Greenier \& Whitehead, 2016). Authentic leadership resonates with the ideas of teachers in kindergarten and needs to be "remaining authentic" in a challenging educational environment (Woodruff, 1996). Authentic leadership consists of four cores (Walumbwa et al., 2008; Avolio \& Walumbwa, 2014): 1) Self-awareness: A continuous process of reflection and self-assessment. The purpose is to understand your strengths, weaknesses and beliefs, and the reasons for these strengths. 2) Relationship transparency: openly share your thoughts and emotions with others; be aware of how to convey your feelings to others, and strive to understand the motives behind your thoughts. 3) Balanced handling: the ability to be objective, considerate, and considerate of various viewpoints, especially opposing viewpoints, and truly eager to explore all viewpoints before making a decision. 4) Internalized morality/ethics: guided by positive values and high moral standards; behaviors and decisions reflect the guiding principles but allow the ability to understand various cultural backgrounds and take appropriate actions.

To be successful, in addition to high ethical standards, classroom teachers also need to have more understanding and appreciation of human nature and personal motivation (Begley, 2006). The main argument behind this model is that educators need to further develop their ability to serve ideal moral purposes (Begley, 2001). Begley and Stefkovich (2007) argue that morality must be regarded as a cultural phenomenon. Therefore, "ethical attitudes are often associated with certain types of administrative decision-making processes and are not always regarded as appropriate by school leaders. Basis. Decision-making in certain administrative situations". Respecting the current organizational rules and policies and the culture of the country/region where you work, while being true to your own beliefs is something that kindergarten teachers must learn to balance. Begley (2006) argued that because morality is usually explained in a culturally exclusive way, and empirical evidence is not necessarily required to justify its adoption, it may be very troublesome that used as values for behavior in schools and 
communities with increasingly diverse cultures.

\subsection{Authentic Leadership and Personality Traits}

People are different from each other in many ways, and personality is one of them. Personality types include outgoing, easy-going, conscientious, neurotic, and open to new experiences, which are also commonly referred to as the Big Five personality traits. Extroversion is an extrovert, talkative, sociable and confident. Agreeableness reflects trust, willingness, kindness, thoughtfulness, tolerance, selflessness, generosity and flexibility. Neuroticism is a characteristic of anxiety, insecurity, self-awareness, depression, and moodiness. Openness to experiences refers to people's imagination, creativity, non-traditional, curiosity, inconsistency, autonomy and aesthetic perception. Conscientiousness describes how reliable, cautious and self-disciplined people are (Bertsch et al., 2017).

However, the research to explore the antecedents of $\mathrm{AL}$ in the existing literature is limited. Only Peus et al. (2012) explored personal self-knowledge and self-consistency as the antecedents of AL. In the past research, the research flow of personality and different leadership clearly defined the particularity of characteristics in leadership prediction behavior. The influence of a person predicts the authenticity of the person whose true leadership style is influential. Given is influential in predicting leadership styles and responding to leadership styles. To explore the antecedents of AL, Shahzad, Raja and Hashmi (2020) studied how the Big Five traits predict AL. They found good support for the proposed hypothesis. Although extraversion, agreeableness, conscientiousness and openness to experience are positively correlated with authentic leadership style and neuroticism is negatively correlated.

The Big Five traits include extraversion, agreeableness, openness to experience, conscientiousness and neuroticism are the most researched and most studied (Costa \& McCrae, 1992; Digman, 1990; Goldberg, 1990). These traits are assumed to be the basic characteristic dimensions in personality psychology. This Big Five model has been cross-culturally tested (McCrae \& Costa, 1997; De Hoogh et al., 2005) and has been studied about different leadership styles, such as ethical leadership, charismatic leadership, transactional leadership, and transformational leadership. Personality traits have always been the core of predicting personal leadership style (Cowley, 1931). Therefore, studying personality traits can predict a person's AL style.

Researchers' interest in leadership traits and the relationship between personality and leadership style has risen and fallen along with the rise and fall of context (Judge et al., 2009). Although most researchers now adopt a comprehensive ("nature in cultivation") position, a model that integrates personality traits, leadership styles, and situations, it is still rare to see (or count attack) the activation of personality traits and leadership styles (De vries, 2018).

\subsection{Hypothesis}

Based on the above, personality has a certain influence on personal leadership. The same is true for teacher leadership. There is a relationship between personality and teacher leadership. So we have the following assumptions:

\section{H1: Personality has a significant impact on teachers' authentic leadership}

\section{Method}

\subsection{Participants}

This study refers to three private kindergartens in Kunming city of Yunnan province, China. The principals of the three kindergartens all agreed to conduct this survey. This survey uses the Chinese questionnaire survey software "Questionnaire Star". After receiving the e-questionnaire link, the principal will forward it to the corresponding teacher by WeChat (one kind of Chinese app). This study uses the convenience sampling method. Responses were both anonymous and voluntary. The study refers to 157 teachers. Women represented $93 \%$ of the sample. The age of the participants included 77 teachers from 18-25 years old, 51 teachers from 26-36 years old, 29 teachers more than 37 years old. Most teachers have 1-5 years of work experience, and this ratio is $84.7 \%$. $73.9 \%$ of teachers are full-time teacher posts, and $26.1 \%$ are staff posts. $51.6 \%$ of them have obtained a college diploma, $30.6 \%$ have a bachelor's degree, and no teachers have obtained a master's degree or above.

\subsection{Instruments}

Five big traits. The Big Five Inventory (Rammstedt \& John, 2007) was used in this study. The questionnaire has 10 items, divided into the following subcategories: Extraversion (example entry: "I am reserved"), Agreeableness (example entry: "I am generally trusting"), Conscientiousness (example entry: "I tend to be lazy"), Neuroticism (example entry: "I am relaxed, handles stress well") and Openness example entry: "I have few 
artistic interests"). Teachers are asked to agree on a 5-point Likert scale, ranging from 1 (strongly disagree) to 5 (strongly agree). The full version of the Big Five Inventory has been verified in Chinese samples (Leung, Wong, Chan, \& Lam, 2013).

Authentic leadership. The study used the Real Leadership Questionnaire of Neider and Schriesheim (2011), which contains 16 questions and is divided into 4 sub-categories: self-awareness, relative transparency, internalization of moral opinions, and balanced processing of information. I adapted the questionnaire from other-report to self-report (Berkovich \& Gueta, 2020). An example of an item from the self-awareness subcategory is: "I solicit feedback to improve my interactions with others." An example of an item in the relative transparency subcategory is: "I clearly state what I mean." An example of a subcategory internalized from a moral perspective is: "I show consistency between my beliefs and actions." The information processing subcategory from balance is: "I seek ideas that challenge my core beliefs." Agree on the Likert 5-point scale, ranging from 1 (strongly disagree) to 5 (strongly agree). The Cronbach $\alpha$ coefficient of this scale is very good, at .81 (Berkovich \& Gueta, 2020).

Teachers responded to their perceptions of authentic leadership and personality. They gave responses by ticking the box that best matched their perceptions. Table 1 presents the corresponding values for the 5-Point Likert scales questionnaires based on the criterion ranging from 5 to 1 , with the interpretation of 5 -strongly agree, 4 -agree, 3-natural, 2-disagree, 1-strongly disagree.

Table 1. Criteria of scale interpretation

\begin{tabular}{llll}
\hline Perception Level & Score & Scale & Interpretation \\
\hline Strongly Agree & 5 & $4.51-5.00$ & Very high \\
Agree & 4 & $3.51-4.50$ & High \\
Natural & 3 & $2.51-3.50$ & Moderate \\
Disagree & 2 & $1.51-2.50$ & Low \\
Strongly Disagree & 1 & $1.00-1.50$ & Very low \\
\hline
\end{tabular}

Note. Norman G. (2010). Likert Scales, Levels of Measurement, and the "Laws" of Statistics.Advances in Health Sciences Education. Vol. 15(5), pp. 625-632.

\subsection{Data Analysis}

We use the linear regression analysis in SPSS 22.0 to verify the research hypothesis that personality has a significant impact on teachers' authentic leadership. In Table 1, teachers reported high scores on the value of relative transparency $(\mathrm{M}=4.0589)$ and low scores on the value of balanced processing of information $(\mathrm{M}=3.9204)$. A measure of teacher authentic leadership (that accounts for all four dimensions revealed a mean score of $3.9829(S D=.37551)$. These general descriptive statistics painted an interesting picture of the current state of teacher authentic leadership in Yunnan private kindergartens. Participants reported neutrality approaching agreement (i.e., hovered around a score of four which is the equivalent of agreement) across the majority of the dimensions. This seemed to suggest that there was significant room to work with teachers on the development of authentic leadership. Participants reported high scores on agreeableness $(\mathrm{M}=3.9777)$ and low scores on neuroticism $(\mathrm{M}=2.8981)$. A measure of teacher's personality (that accounts for all five dimensions revealed a mean score of $3.4783(S D=.30849)$.

In Table 2, as for self-awareness, the overall Mean is 3.9283, which is high but has room to improve. The highest Mean is "I solicit feedback to improve my interactions with others," while the lowest Mean is "I am aware of the impact I have on others." As for relative transparency, the overall Mean is 4.0589, which is high but has room to improve. The highest Mean is "I admit mistakes when occur," while the lowest Mean is "I openly share information with others." As for the internalization of moral opinions, the overall Mean is 4.0239, which is high but has room to improve. The highest Mean is "I am guided in my actions by internal moral standards," while the lowest Mean is "I resist pressures on myself to do things contrary to my beliefs." As for balanced processing of information, the overall Mean is 3.9204, which is high but has room to improve. The highest Mean is "I carefully listen to alternative perspectives before concluding," while the lowest Mean is "I encourage others to voice opposing points of view." 
Table 2. Descriptive for the study

\begin{tabular}{|c|c|c|c|c|c|}
\hline \multirow[t]{2}{*}{ Descriptive Statistics } & \multirow[b]{2}{*}{$\mathrm{N}$} & \multirow[b]{2}{*}{ Minimum } & \multirow[b]{2}{*}{ Maximum } & \multirow[b]{2}{*}{ Mean } & \multirow[b]{2}{*}{ Std. Deviation } \\
\hline & & & & & \\
\hline S1 & 157 & 1 & 5 & 4.13 & .723 \\
\hline R1 & 157 & 1 & 5 & 4.10 & .597 \\
\hline M1 & 157 & 1 & 5 & 4.02 & .702 \\
\hline B1 & 157 & 1 & 5 & 3.83 & .783 \\
\hline S2 & 157 & 3 & 5 & 3.78 & .592 \\
\hline R2 & 157 & 3 & 5 & 4.37 & .535 \\
\hline M2 & 157 & 2 & 5 & 3.99 & .572 \\
\hline B2 & 157 & 3 & 5 & 4.26 & .556 \\
\hline S3 & 157 & 3 & 5 & 4.07 & .590 \\
\hline R3 & 157 & 1 & 5 & 3.81 & .752 \\
\hline M3 & 157 & 1 & 5 & 3.89 & 1.023 \\
\hline B3 & 157 & 2 & 5 & 4.02 & .615 \\
\hline S4 & 157 & 2 & 5 & 3.73 & .692 \\
\hline R4 & 157 & 3 & 5 & 3.96 & .598 \\
\hline M4 & 157 & 1 & 5 & 4.19 & .671 \\
\hline B4 & 157 & 1 & 5 & 3.57 & .915 \\
\hline $\mathrm{P} 1$ & 157 & 1 & 5 & 2.73 & .916 \\
\hline P2 & 157 & 3 & 5 & 4.31 & .587 \\
\hline P3 & 157 & 1 & 5 & 3.97 & .865 \\
\hline P4 & 157 & 1 & 5 & 2.46 & .694 \\
\hline P5 & 157 & 1 & 5 & 3.61 & .889 \\
\hline P6 & 157 & 1 & 5 & 3.41 & .832 \\
\hline P7 & 157 & 1 & 5 & 3.64 & .768 \\
\hline P8 & 157 & 1 & 5 & 3.76 & .769 \\
\hline P9 & 157 & 1 & 5 & 3.33 & .901 \\
\hline P10 & 157 & 2 & 5 & 3.54 & .738 \\
\hline Leadership & 157 & 3.19 & 5.00 & 3.9829 & .37551 \\
\hline Personality & 157 & 2.80 & 4.30 & 3.4783 & .30849 \\
\hline self & 157 & 2.75 & 5.00 & 3.9283 & .45384 \\
\hline relative & 157 & 3.25 & 5.00 & 4.0589 & .42474 \\
\hline moral & 157 & 3.00 & 5.00 & 4.0239 & .46322 \\
\hline Balance & 157 & 3.00 & 5.00 & 3.9204 & .46171 \\
\hline extra & 157 & 1.00 & 5.00 & 3.0732 & 69295 \\
\hline consci & 157 & 2.00 & 5.00 & 3.8662 & .62630 \\
\hline agree & 157 & 3.00 & 5.00 & 3.9777 & .50110 \\
\hline neuro & 157 & 1.00 & 4.50 & 2.8981 & .61691 \\
\hline open & 157 & 2.00 & 5.00 & 3.5764 & .63591 \\
\hline Valid N (listwise) & 157 & & & & \\
\hline
\end{tabular}

Note. S (self-awareness), R (relative transparency), M (internalization of moral opinions), B (balanced processing of information), $\mathrm{P}$ (personality).

In the first part of Linear Regression, the researcher aimed to test to what degree the personality contributed to the teacher authentic leadership. Table 3 below indicated the results of the data analysis. The R-value was .358, which indicated the correlation between personality and teacher authentic leadership was 0.358 . The R Square was .128, there were able to predict $12.8 \%$ of the variance of this model, which meant the percentage that teacher authentic leadership was predicted by personality was $12.8 \%$. According to the data analysis result, the P-value was less than .05 , personality significantly impacted the teacher's authentic leadership. 
Table 3. Linear regression results of the survey data related to the personality impact on teachers' authentic leadership $(\mathrm{n}=157)$

\begin{tabular}{lllll}
\hline Model & $\mathrm{R}$ & $\mathrm{R}$ Square & $\begin{array}{c}\text { Model Summary } \\
\text { Adjusted R Square }\end{array}$ & Std. Error of the Estimate \\
\hline 1 & $.358^{\mathrm{a}}$ & .128 & .122 & .35177 \\
\hline a. Predictors: (Constant), Personality & & \\
\hline
\end{tabular}

\begin{tabular}{lllllll}
\hline \multicolumn{7}{c}{ NNOVA $^{\text {a }}$} \\
Model & \multicolumn{7}{c}{ Sum of Squares } & df & Mean Square & F & Sig. \\
\hline 1 & Regression & 2.817 & 1 & 2.817 & 22.763 & $.000^{\mathrm{b}}$ \\
& Residual & 19.180 & 155 & .124 & & \\
& Total & 21.997 & 156 & & & \\
\multicolumn{2}{l}{ a. Dependent Variable: Leadership. } & b. Predictors: (Constant), Personality \\
\hline
\end{tabular}

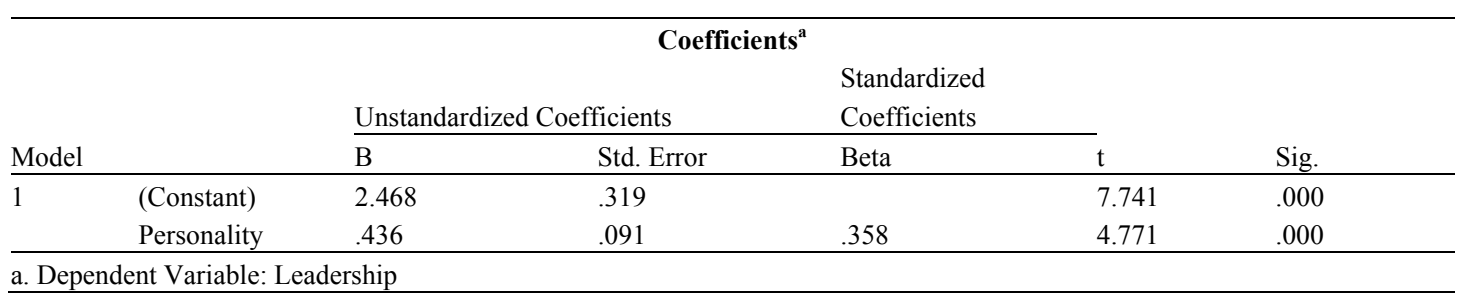

\section{Discussion}

Yunnan province is located in the southwestern region of China and is an underdeveloped province. Teacher leadership in this area is not well developed, hence schools need to take corresponding measures to improve teacher leadership (Yue \& Feng, 2021). Many teachers graduated from normal universities in Yunnan province, while there is little leadership training (Yue, 2021). From the data results, the leadership of kindergarten teachers in Yunnan needs to be further improved.

Twenty years ago, the study of the personality of the great leader has lifted the veil of the celebrity. This is partly due to leadership theories obtained in the magic or field, which believes that personality predicts leader behavior and merit. Besides, it is in satisfaction. Various interests can provide results for a new framework on personality factors (De Hoogh et al., 2005). Many studies have found that the five personality traits are related to different leadership behaviors and leadership effectiveness. The relationship between character and leadership is very stable (Kalshoven et al., 2011). Researchers focus on the correlation between personality traits and leadership (Hendricks \& Payne, 2007).

In the study of Rammstedt and John (2007), they found that results from multiple samples with two languages, namely English and German personality traits data. Given its simplicity, BFI-10 has acceptable psychometric properties. However, compared with the full version of BFI, the loss is great. Therefore, if the test time is not extremely limited, the complete five personalities have a clear psychological measurement advantage. In other words, ultra-short measurements should not and cannot be used as a substitute for conventional personality assessment. It is only suitable for participants whose time is really limited, otherwise, personality cannot be evaluated. For example, in telephone surveys, BFI-10 can be used to fully evaluate personality. In this study, we also found that the reliability of short questionnaires is not high when doing personality trait tests. In the future, researchers should use complete questionnaires and avoid short questionnaires when doing personality tests.

\section{Conclusion and Future Research}

The leadership of private kindergarten teachers in Yunnan needs to be further improved. Local universities can provide leadership training for kindergarten teachers. Personality is very important as a prerequisite to influence the development of leadership, and the study of the relationship between individuals and leadership should be re-emphasized. When testing personality traits in the future, a complete questionnaire should be used. The limitation of this study is that it did not use the full version of the questionnaire. Future research must use the full version of the questionnaire and can add public kindergarten teacher leadership data, through comparison to see the difference between public and private. In the future, we will continue to study how to improve the influence of personality to promote the development of teacher leadership. 


\section{References}

Avolio, B. J., \& Gardner, W. L. (2005). Authentic leadership development: Getting to the root of positive forms of leadership. The Leadership Quarterly, 16(3), 315-338.

Avolio, B. J., Gardner, W. L., Walumbwa, F. O., Luthans, F., \& May, D. R. (2004). Unlocking the Mask: A Look at the Process by Which Authentic Leaders Impact Follower Attitudes and Behaviors. The Leadership Quarterly, 15(6), 801-823. https://doi.org/10.1016/j.leaqua.2004.09.003

Avolio, B. J., \& Walumbwa, F. O. (2014). Authentic leadership theory, research and practice: Steps taken and steps that remain. In D. Day (Ed.), The Oxford Handbook of Leadership and Organizations (pp. 331-356). New York: Oxford University Press.

Begley, P. (2006). Self-knowledge, capacity and sensitivity: Perquisites to authentic leadership among principals. Journal of Educational Administration, 44(6), 570-590.

Begley, P. T. (2001). In pursuit of authentic school leadership practices. International Journal of Leadership in Education, 4(4), 353-365. https://doi.org/10.1080/13603120110078043

Begley, P. T., \& Stefkovich, J. (2007). Integrating values and ethics into post-secondary teaching for leadership development: Principles, concepts, and strategies. Journal of Educational Administration, 45(4), 398-412.

Berkovich, I., \& Gueta, B. (2020). Teachers' authentic leadership and psychological need satisfaction climate in second chance programmes: The moderating role of teachers' gender. Educational Management Administration \& Leadership. https://doi.org/10.1177/1741143220957340

Bertsch, A., Nguyen, H. T. H., Alford, A., Baran, W., Reynen, J., Saeed, M., ... De Hoogh, A. H. B. (2011). Ethical leader behavior and big five factors of personality. Journal of Business Ethics, 100(2), 349-366. https://doi.org/10.1007/s10551-010-0685-9

Costa, P. T. Jr., \& McCrae, R. R. (1992). Four Ways Five Factors are Basic. Personality Individual Differences, $13,653-665$.

De Hoogh, A. H. B., Den Hartog, D. N., \& Koopman, P. L. (2005). Linking the Big Five-Factors of personality to charismatic and transactional leadership; perceived dynamic work environment as a moderator. Journal of Organizational Behavior, 26(7), 839-865. https://doi.org/10.1002/job.344

De Vries, R. (2018) Three Nightmare Traits in Leaders. Front. Psychol., 9, 871. https://doi.org/10.3389/fpsyg.2018.00871

Greenier, V., \& Whitehead, G. E. K. (2016). Towards a model of teacher leadership in ELT: Authentic leadership in classroom practice. RELC Journal, 47, 79-95. https://doi.org/10.1177/0033688216631203

Halttunen, L., Waniganayake, M., \& Heikka, J. (2019). Teacher leadership repertoires in the context of early childhood education team meetings in Finland. Journal of Early Childhood Education Research, 8(1), $143-161$.

Retrieved

from https://jecer.org/fi/wp-content/uploads/2019/10/Halttunen-Waniganayake-Heikka-issue8-1.pdf

Harris, A. (2003). Teacher leadership as distributed leadership: Heresy, fantasy or possibility. School Leadership \& Management, 23, 313-324. https://doi.org/10.1080/1363243032000112801

Harris, A. (2005). Teacher leadership: More than just a feel-good factor? Leadership and Policy in Schools, 4, 201-219. https://doi.org/10.1080/15700760500244777

Heikka, J. (2014). Distributed pedagogical leadership in early childhood education. Acta Electronica Universitatis Tamperensis 1392. University of Tampere, Finland.

Heikka, J., Halttunen, L., \& Waniganayake, M. (2018). Perceptions of early childhood education professionals on teacher leadership in Finland. Early Child Development and Care, 188(2), 143-156.

Heikka, J., Pitkäniemi, H., Kettukangas, T., \& Hyttinen, T. (2019). Distributed pedagogical leadership and teacher leadership in early childhood education contexts. International Journal of Leadership in Education. 60(3), 333-348. https://doi.org/10.1080/13603124.2019.1623923

Heikka, J., Pitkäniemi, H., Kettukangas, T., \& Hyttinen, T. (2021). Distributed pedagogical leadership and teacher leadership in early childhood education contexts. International Journal of Leadership in Education, 24(3), 333-348, https://doi.org/10.1080/13603124.2019.1623923

Heikka, J., \& Waniganayake, M. (2011). Pedagogical leadership from a distributed perspective within the context of early childhood education. International Journal of Leadership in Education, 14, 499-512. 
https://doi.org/10.1080/13603124.2011.577909

Heikka, J., Waniganayake, M., \& Hujala, E. (2013). Contextualizing distributed leadership within early childhood education current understandings, research evidence and future challenges. Educational Management Administration \& Leadership, 41(1), 30-44. https://doi.org/10.1177/1741143212462700

Hendricks, J. W., \& Payne, S. C. (2007). Beyond the big five: Leader goal orientation as a predictor of leadership effectiveness. Human Performance, 20, 317-343.

Ho, D., Wang, M. O., \& He, P. (2019). The Changing Landscape of Leadership in Early Childhood Education in China, Teacher Education in the 21st Century. Retrieved from https://www.intechopen.com/books/teacher-education-in-the-21st-century/thechanging-landscape-of-leader ship-in

Katzenmeyer, M., \& Moller, G. (2009). Awakening the Sleeping Giant: Helping Teachers Develop as Leaders (3rd ed.). Thousand Oaks, CA: Corwin Press.

Leung, D. Y., Wong, E. M., Chan, S. S., \& Lam, T. (2013). Psychometric properties of the Big Five Inventory in a Chinese sample of smokers receiving cessation treatment: A validation study. Journal of Nursing Education \& Practice, 3(6), 1-10.

Luthans, F., \& Avolio, B. (2003). Authentic leadership development. In K. Cameron \& J. Dutton (Eds.), Positive organizational scholarship (pp. 241-258). San Francisco, CA: Berrett-Koehler Publishers.

Neider, L. L., \& Schriesheim, C. A. (2011). The authentic leadership inventory (ALI): Development and empirical tests. Leadership Quarterly, 22(6), 1146-1164. https://doi.org/10.1016/j.leaqua.2011.09.008

Norman, G. (2010). Likert scales, levels of measurement and the "laws" of statistics. Adv Health Sci Educ Theory Prac., 15(5), 625-632. https://doi.org/10.1007/s10459-010-9222-y

Ondracek, J. (2017). Exploring the relationship between personality and preferred leadership. Journal of Leadership, Accountability and Ethics, 14(1). Retrieved from http://www.academia.edu/32379913/Exploring_the_Relationship_Between_Personality_and_Preferred_Lea dership

Peus, C., Wesche, J. S., Streicher, B., Braun, S., \& Frey, D. (2012). Authentic leadership: An empirical test of its antecedents, consequences, and mediating mechanisms. Journal of Business Ethics, 107(3), 331-348. https://doi.org/10.1007/s10551-011-1042-3

Shahzad, K., Raja, U., \& Hashmi, S. D. (2020). Impact of Big Five personality traits on authentic leadership. Leadership \& Organization Development Journal.

Walumbwa, F. O., Avolio, B. J., Gardner, W. L., Wernsing, T. S., \& Peterson, S. J. (2008). Authentic leadership: development and validation of a theory-based measure. Journal of Management, 34(1), 89-126.

Wang, M. (2018). Perceptions and Its Influencing Factors of Teacher Leadership in Early Childhood Education in China. Doctoral dissertation, The Education University of Hong Kong, Hong Kong.

Wang, M., \& Ho, D. (2019). A quest for teacher leadership in the twenty-first century emerging themes for future research. International Journal of Educational Management, 34(2). https://doi.org/10.1108/IJEM-01-2019-0038

Wang, M., \& Xia, J. (2020). A scale for measuring teacher leadership in early childhood education in China: Development and validation. Educational Management Administration \& Leadership. https://doi.org/10.1177/1741143220949546

Wiewiora, A., \& Kowalkiewicz, A. (2018). The role of authentic assessment in developing authentic leadership identity and competencies. Assessment \& Evaluation in Higher Education, 44(3), 415-430. https://doi.org/10.1080/02602938.2018.1516730

Woodruff, D. W. (1996). 'Keeping it real': The importance of community in multicultural education and school success. Theory into Practice, 35(4), 278-282.

York-Barr, J., \& Duke, K. (2004). What do we know about teacher leadership? Findings from two decades of scholarship. Review of Educational Research, 74(3), 255-316.

Yue, X. Y. (2021). The Development of a Training Program to Improve Students' Social Leadership Capacity in Normal Universities of Yunnan Province. Doctoral dissertation (in press)

Yue, X. Y., \& Feng, Y. J. (2021). Empirical Research on Leadership Capacity of Secondary Vocational Teachers 
in Yunnan Province of China. Journal of Education and Learning, 10(1), 7-21. ISSN 1927-5250.

\section{Copyrights}

Copyright for this article is retained by the author, with first publication rights granted to the journal.

This is an open-access article distributed under the terms and conditions of the Creative Commons Attribution license (http://creativecommons.org/licenses/by/4.0/). 